\title{
$50 \mathrm{~W}$ 급 LED 보안등용 조명광학계 개발
}

\author{
정병조 ${ }^{*}$, 장성환 $^{1}$, 노용기 ${ }^{2}$ \\ ${ }^{1}$ 원광대학교 전기공학과, ${ }^{2}$ 전북인력개발원 전기시스템제어과

\section{Development of Optical System for 50W LED Security Lamp}

\author{
Jung Byoung-Jo ${ }^{1 *}$, Jang Sung-Whan ${ }^{1}$ and Roh Yong-Gi ${ }^{2}$ \\ ${ }^{1}$ Dept. of Electrical Engineering, Wonkwang University \\ ${ }^{2}$ Dept. of Electrical System Control, KCCI JBHRDI
}

\begin{abstract}
요 약 본 연구에서는 기존 LED 보안등의 LED 광원 직진성에 의한 눈부심 현상을 개선하고, 조도 균제도를 높게 유지하며, 회전 대칭이 아닌 편축으로 긴 배광 분포를 가지도록 하여 LED 보안등 간에 생기는 광 공핍현상을 해결할 수 있는 보안등용 LED 2차 렌즈를 개발하였다. 개발 광학계는 보안등용 조명 기준에 만족하도록 설계하였으며, 렌즈 의 형태는 단일 렌즈로 조명 설계 및 해석 프로그램을 이용한 설계와 분석을 통해 최적화를 하였다. Mock-up을 제작 하여 실제 측정을 통해 조도 측정 데이터와 조도 균제도 데이터를 확보하였다.
\end{abstract}

\begin{abstract}
In this paper, we develop about glare phenomenon at security light caused by light source's straight characteristic, maintaining uniformity ratio of illuminance as high, have long light distribution not by symmetry of rotation but a single axis. we develop second lens for security light that lack of light distribution phenomenon at each of security light can be solved. Our developed light system design satisfies lighting standard of security light's and shape of lens is single lens. so our lens optimizes designing or analysis by using lighting design and interpretation program. Making a Mock-up to do real measure, we have intensity of illumination and maintaining uniformity ratio of illuminance measurement data.
\end{abstract}

Key Words : LED, Security light, Eye-safety, Light Uniformity, Second Lens

\section{1. 서론}

에너지 절감과 환경문제가 대두되면서 세계적으로 에 너지 절감을 위한 노력이 진행되고 있다. 조명 시장에서 도 조명의 대표 주자인 백열전구가 낮은 효율과 이산화 탄소 발생 등의 환경문제로 사용이 금지되고 있으며, 실 제로 우리 정부에서도 고효율 전력기기 사용을 늘림으로 써 전력수요를 줄이기 위한 전력효율 향상사업에 주력하 고 있다.[1] 그렇기 때문에 상대적으로 광효율 $(\mathrm{lm} / \mathrm{W})$ 이 높은 LED 조명기구가 연구 개발되어 이미 조명시장에서 자리매김 해가고 있다.

LED 광원에 비해 기존에 사용되던 메탈할라이드, 수 은, 고압 나트륨 등의 광원은 환경과 효율의 문제를 가지
고 있다. 또한 점광원에 가까운 기존 등에 비해 $\mathrm{LED}$ 는 면광원에 가깝고 이러한 면광원 특성은 램버시안 방사로 한쪽 방향으로만 방사되어 기존 조명에 비해 상대적으로 직진성이 심한 특징을 갖는다. 이 특징은 조명용으로 $\mathrm{LED}$ 를 사용할 경우 광 균일도가 좋지 못하다는 단점을 갖게 한다. 조명 등의 다목적으로 LED 광원을 이용하기 위해서는 제품 개발 전에 충분한 광학적 특성 분석을 통 하여 목적에 맞는 배광특성을 갖는 광원을 사용하여야 한다.[2]

기존의 LED 보안등은 다수의 낮은 출력의 $\mathrm{LED}$ 를 배 열하여 사용하는 방법으로 다수의 렌즈를 제작해야 하기 때문에 제작비용이 많이 들고, 거리와 방향에 따라 배광 이 달라 광제어가 어렵기 때문에 눈부심이 강하고 광균

본 눈문은 2011년도 원광대학교 교내연구비의 지원으로 수행되었음.

"교신저자 : 정병조(zpk@lycos.co.kr)

접수일 11년 10월 12 일

수정일 (1차 11년 11월 10일, 2차 12년 01월 03일)

게재확정일 12 년 01 월 05 일 
일도가 좋지 않아 실제로 설치할 경우 다수의 보안등을 촘촘하게 설치해야 하는 단점이 있다. 또한 직진성이 강 한 성질을 적절히 조절하지 못하기 때문에 조도 균제도 등의 도로 조명 기준을 만족시키지 못하고 있다.

본 연구에서는 기존 LED 보안등의 LED 광원 직진성 에 의한 눈부심 현상을 개선하고, 조도 균제도를 높게 유 지하며, 회전 대칭이 아닌 편축으로 긴 배광 분포를 적절 히 가지도록 하여 LED 보안등 간에 생기는 광 공핍현상 을 해결할 수 있는 보안등용 고출력 LED 2차 렌즈를 개 발하였다. 개발 광학계는 도로 조명 기준에 만족하도록 설계하였으며, 렌즈의 형태는 단일 렌즈로 $3 \mathrm{D} \mathrm{CAD} \mathrm{프로}$ 그램과 조명 설계 해석 프로그램을 이용한 설계와 분석 을 통해 최적화를 행하고, Mock-up을 제작하여 공인시험 기관에서 측정하여 데이터를 확보하였다.

\section{2. 본론}

\section{1 조도}

조도는 일정한 평면이 밝게 비추이는 정도를 말하며, 조명되는 면적과 광속의 비율로 결정된다. 어떤 물체에 광속이 투사되면 그 면은 밝게 비추어진다. 그 정도를 표 시하는데 조도가 사용된다. 어떤 면의 조도는 그 면에 투 사되는 광속의 밀도를 말한다. 즉 어떤 면에서의 입사 광 속의 면적 당 밀도는 그 면의 조도(E)다. 그림 1에서 면적 $\mathrm{S}\left(\mathrm{m}^{2}\right)$ 에 균일하게 광속 $\mathrm{F}(\mathrm{lm})$ 이 투사되고 있을 때, 이면의 평균조도 $\mathrm{E}$ 는 다음의 관계가 성립된다.[3]

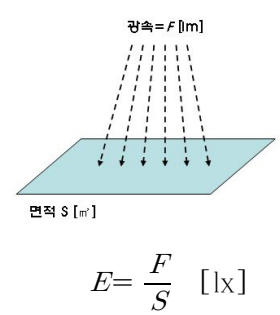

[그림 1] 조도

[Fig. 1] Illumination

1 럭스(lux)란 MKS 단위로 $1\left(\mathrm{~m}^{2}\right)$ 에 $1(\mathrm{~lm})$ 의 광속이 입 사할 때의 조도이다. 그러므로 $1(\mathrm{~lx})=1\left(\mathrm{~lm} / \mathrm{m}^{2}\right)$ 라 할 수 있다.

\section{2 광학특성과 광 변환 효율}

LED 반도체는 본질적으로 방향성 광원은 아니나 구 조적으로 불투명성 요소(기판, 전극, 방열기 등)에 의한
빛 손실을 최소화한 광학적 디자인으로 작은 반사경과 에폭시 렌즈를 사용하여 전면에 빛을 모아 발산하는 구 조를 사용하고 있다. 이에 따라 패키징 된 LED 램프는 방향성을 가지고 있으며, 광학특성도 이러한 구조에서 측 정하는 것이 일반적이다.[4]

광 변환 효율(Lumen Per Watt)은 반도체기술 발전과 더불어 매 18 개월 주기로 약 2 배 향상되고 있으며, 현재 실험적으로 $100 \mathrm{~lm} / \mathrm{W}$ 이상 보고되고 있다. 그러나 양산되 는 상용제품은 30 40lm/W수준이다. 이는 백열전구 광 변환 효율 $10 \sim 15 \mathrm{~lm} / \mathrm{W}$ 의 약 2.5 배, 형광등 광 변환 효율 $70 \sim 80 \mathrm{~lm} / \mathrm{W}$ 의 약 $1 / 2$ 에 해당하는 것이다. 가시광선의 좁 은 파장대를 발광하는 $\mathrm{LED}$ 광원은 적외선과 자외선 방 출에 의해 대기로의 열전달은 거의 없는 반면 접합부분 에서 높은 열을 발생한다. 이러한 열 발생은 LED 성능을 크게 좌우하므로 조명시스템 설계시 열처리 기술은 매우 중요한 요인의 하나로 고려된다. 표 1 은 입력전력에 대한 주요 광원의 광 출력, IR/UV 출력, 열 발생, 안정기 손실 에 대한 비율로써 기존 광원의 경우 IR 발생비율이 높은 반면 $\mathrm{LED}$ 의 경우 열 발생비율이 높은 것을 알 수 있다. $\mathrm{IR}$ 과 $\mathrm{UV}$ 가 적다는 것은 빛에 의해 피사체에 전달되는 에너지가 적다는 의미로 외부로 적절히 열을 방출할 경 우 박물관 조명, 냉동냉장고의 내부 조명에 우수한 효과 를 기대할 수 있다.

[표 1] 입력전력에 대한 주요광원의 출력

[Tabel 1] The output of the main sources for the input power

\begin{tabular}{l|c|c|c|c|c}
\hline \multicolumn{2}{|c|}{} & $\begin{array}{c}\text { Electric } \\
\text { bulb } \\
\text { (60W) }\end{array}$ & $\begin{array}{c}\text { Fluorescent } \\
\text { (amp } \\
\text { (Intuition) }\end{array}$ & $\begin{array}{c}\text { Metalarc } \\
\text { lamp }\end{array}$ & LED \\
\hline \hline \multirow{2}{*}{$\begin{array}{c}\text { Radiant } \\
\text { energy }\end{array}$} & $\begin{array}{c}\text { Visible } \\
\text { rays (V) }\end{array}$ & $8 \%$ & $21 \%$ & $27 \%$ & $15 \sim 25 \%$ \\
\cline { 2 - 6 } & $\begin{array}{l}\text { Infrared } \\
\text { ray (IR) }\end{array}$ & $73 \%$ & $37 \%$ & $17 \%$ & $0 \%$ \\
\cline { 2 - 6 } & $\begin{array}{c}\text { Ultraviolet } \\
\text { rays(UV) }\end{array}$ & $0 \%$ & $0 \%$ & $19 \%$ & $0 \%$ \\
\cline { 2 - 6 } & Total & $81 \%$ & $58 \%$ & $63 \%$ & $15 \sim 25 \%$ \\
\hline $\begin{array}{l}\text { Heat(conduction+ra } \\
\text { diation) energy }\end{array}$ & $19 \%$ & $42 \%$ & $37 \%$ & $75 \sim 85 \%$ \\
\hline \multicolumn{2}{|c|}{ 계 } & $100 \%$ & $100 \%$ & $100 \%$ & $100 \%$ \\
\hline
\end{tabular}

\section{3. 실험방법}

\section{1 광학설계 및 조명 시뮬레이션}

\subsection{1 광학설계}

렌즈의 광학 설계를 위해 OSLO 광학 프로그램을 사 용하였고, 설계의 목적은 직진성이 강한 $\mathrm{LED}$ 의 배광 분 
포를 도로 조명 기준에 적합하도록 넓히는 것이다. 본 개 발 광학계는 광확산을 통해 광균일도를 유지하고 근본적 으로 눈부심을 억제하는 보안등용 렌즈로 축대칭 광학계 이며 렌즈의 모양이 땅콩(Peanut)의 형상을 닮았다. 그림 2 와 그림 3 은 광학 설계 프로그램인 $\mathrm{OSLO}$ 를 이용하여 본 광학계를 설계한 것이다.

그림 2는 광학 설계 프로그램으로 배광을 넓히고 조도 균제도를 높게 설계한 렌즈이다. 렌즈의 내부는 옆으로 빠지는 광을 중심부로 모아주는 역할을 하고 렌즈의 외 부는 퍼트려주는 역할을 하게 된다.

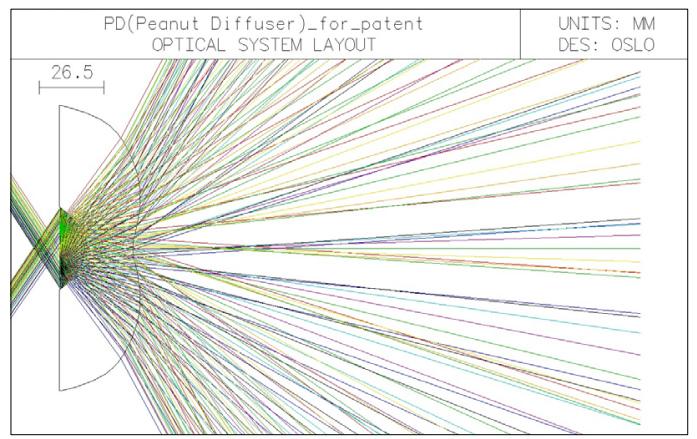

(a) $2 \mathrm{D}$ 광학설계

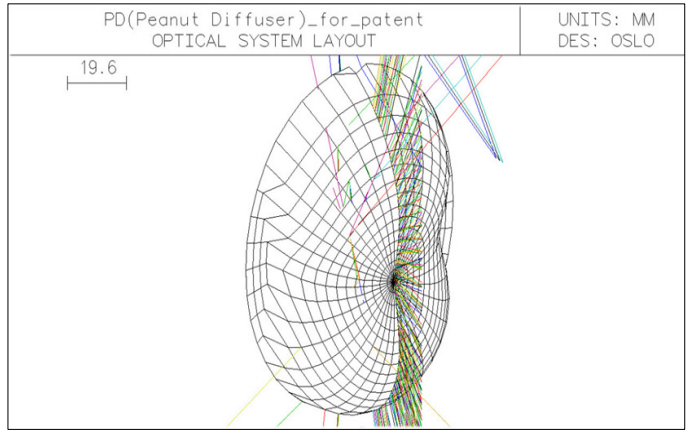

(b) $3 \mathrm{D}$ 광학설계

[그림 2] 광학계 설계(OSLO)

[Fig. 2] Optical design(OSLO)

식 (1)은 일반적인 $\mathrm{X}$ 축 방향으로 평행하게 회전하는 $\mathrm{X}$-Toric 곡선 비구면방정식이다.

$$
\begin{aligned}
& z=\frac{c v\left[y^{2}-g^{2}(x)\right]+2 g(x)}{1+\sqrt{1-c v\left(c v\left[y^{2}-g^{2}(x)\right]+2 g(x)\right)}} \\
& +a s_{2} x^{4}+a s_{3} x^{6}+a s_{4} x^{8}+a s_{5} x^{10}+\cdots \\
& g(x)=\frac{c v_{x} x^{2}}{1+\sqrt{1-c v_{x}^{2}\left(c c_{x}+1\right) x^{2}}} \\
& \quad+a s a 4 x^{4}+a s a 6 x^{6}+a s a 8 x^{8}+a s a 10 x^{10}+\cdots
\end{aligned}
$$

$$
y^{2}=(c c+1) y^{\prime 2}
$$

여기서, $c v$ 는 면의 곡률이고, $c c$ 는 원추 계수라고 부 르는 상수이다. $a s_{2}, a s_{3}, a s_{4}, a s_{5} \cdots$ 등은 비구면 계수이 며, 원추곡면에서 벗어난 정도를 의미한다. $c v_{x}$ 는 $\mathrm{X}$ 축 Toric면의 곡률이고, $c c_{x}$ 는 $\mathrm{X}$ 축의 원추 계수이다.

그림 3은 OSLO에서 식 (1)을 통해 만들어진 형상이 다. 광학 설계 프로그램을 사용하여 가능한 고차항의 비 구면 계수를 사용해도 원하는 형상이나 결과물을 얻지 못하는 경우가 있다. 주요 부위가 아닌 위치에서 수치상 으로 제거가 힘든 부분이 있었고, $\mathrm{A}$ 와 $\mathrm{B}$ 의 부위는 큰 역 할을 하지 않는 부분이지만 끊어져있고 표면이 매끄럽지 못했다. 이를 해결하기 위해 $3 \mathrm{D}$ 설계 프로그램인 SolidWorks를 사용하여 마무리가 미비한 부분들을 해결 하였다. 그림 4는 OSLO에서 설계한 데이터를 기초로 하 여 Solidworks에서 렌즈의 형상을 설계한 모습이다.

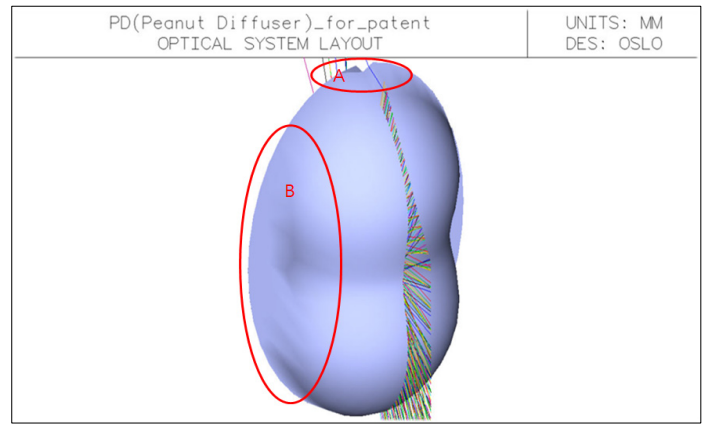

[그림 3] 3D 광학계 설계(OSLO)

[Fig. 3] Optical design of 3D(OSLO)

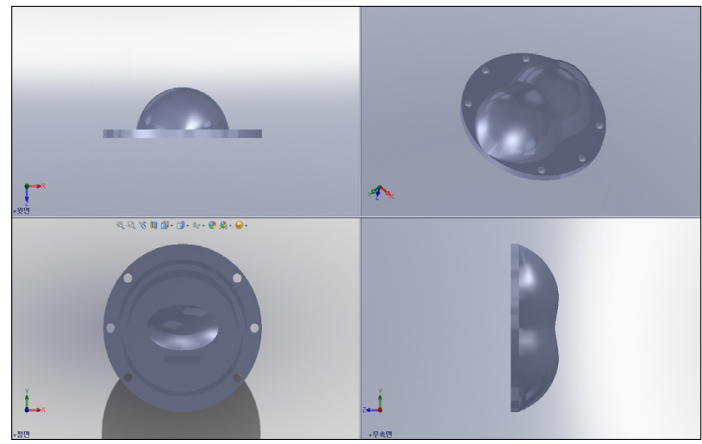

[그림 4] 3D 광학계 설계(Solidworks)

[Fig. 4] Optical design of 3D(Solidworks)

\subsection{2 조명 시뮬레이션}

$3 \mathrm{D}$ 로 설계한 개발 광학계를 사용하여 조명 시뮬레이 
션을 실시하였다. 조명 시뮬레이션은 조명 시뮬레이션 전 용 프로그램인 LightTools를 사용하였다. 그림 5는 개발 광학계를 LightTools에서 시뮬레이션 한 모습으로, 광원 에서 나온 광의 방향을 확인 할 수 있다. 본 개발 광학계 는 High Power용 렌즈로 Multi Chip Array LED에 사용 하며, Low Quality한 LED에도 사용이 가능하도록 설계 하였다. 시뮬레이션은 Multi Chip Array LED를 사용하였다.

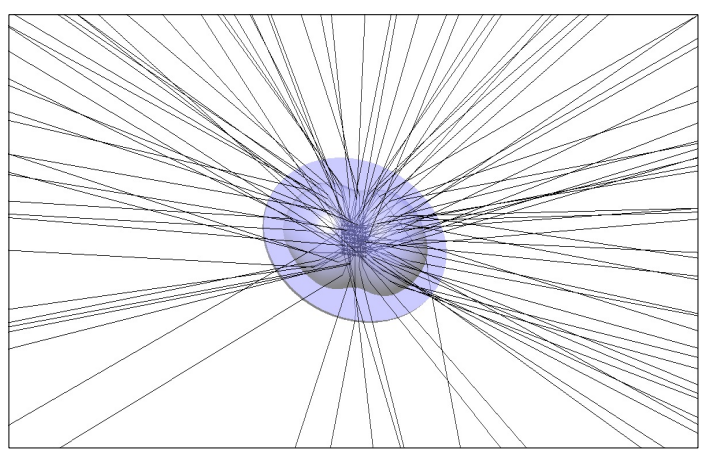

[그림 5] LightTools에서의 조명 시뮬레이션

[Fig. 5] Lighting Simulation in LightTools

개발 광학계는 그림 6의 (a)의 내부 타원면에서 LED 파워를 조절하고, (b)의 외부 비구면에서 광을 확산하는 역할을 한다.
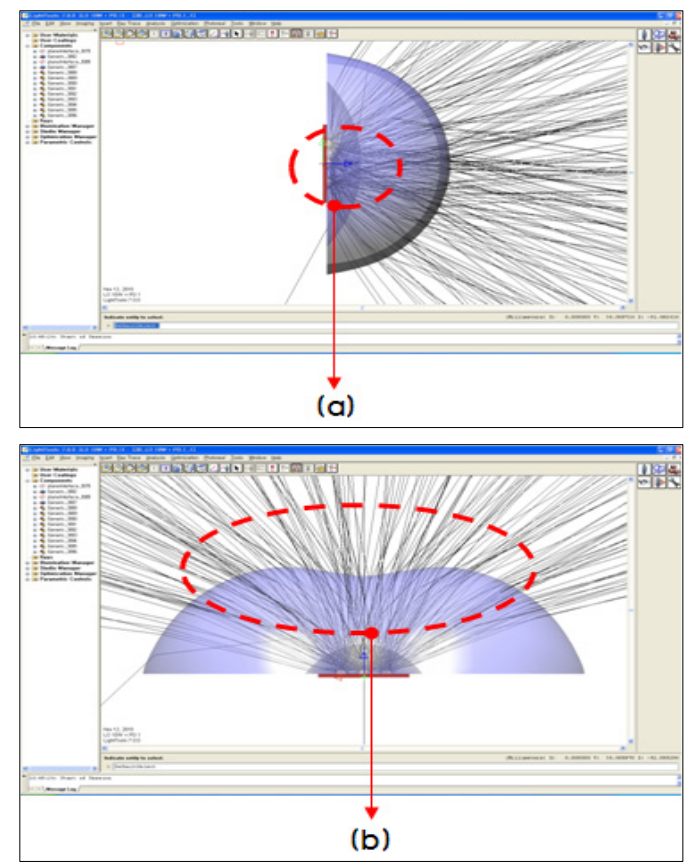

[그림 6] 개발 광학계 광선도

[Fig. 6] Development of optical beams
LED 보안등기구의 설치 높이는 현재 많이 적용되고 있는 $4 \mathrm{~m}, 5 \mathrm{~m}, 6 \mathrm{~m}$ 의 세 종류에 대해서 적용한다. 또한 설 치 높이에 따른 조도 계산 영역은 $4 \mathrm{~m}$ 일 때 $8 \mathrm{~m} \times 4 \mathrm{~m}$ 이고, $5 \mathrm{~m}$ 일 때 $12 \mathrm{~m} \times 6 \mathrm{~m}$ 이며, $6 \mathrm{~m}$ 일 때 $16 \mathrm{~m} \times 8 \mathrm{~m}$ 의 적용 면적으 로 측정함을 원칙으로 한다. 그림 7은 LED 모듈을 각각 $4 \mathrm{~m}, 5 \mathrm{~m}, 6 \mathrm{~m}$ 설치 높이에서 조도 상태를 시뮬레이션 그 림을 나타낸다. 그림 7의 (a), (b), (c)를 살펴보면 중심 부 분으로 광이 집중됨을 알 수 있다.

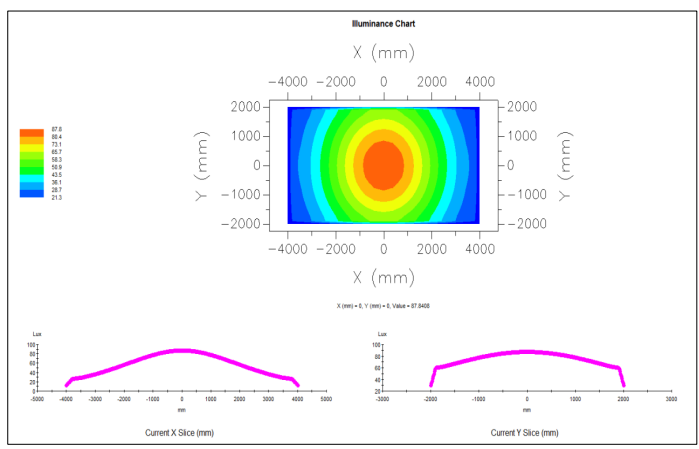

(a) $4 \mathrm{~m}$ 설치 높이의 조도 시뮬레이션

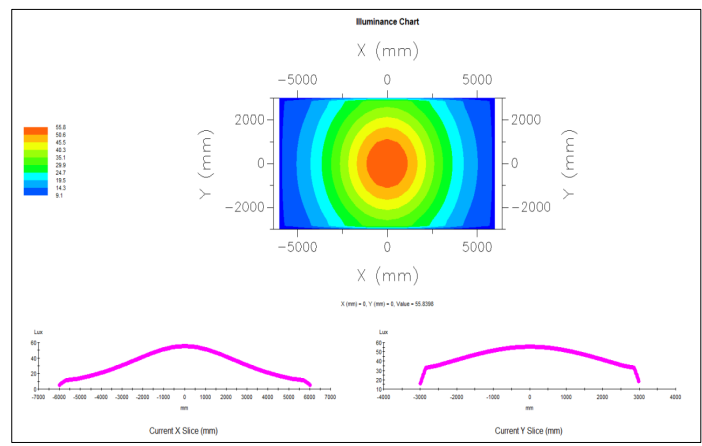

(b) $5 \mathrm{~m}$ 설치 높이의 조도 시뮬레이션

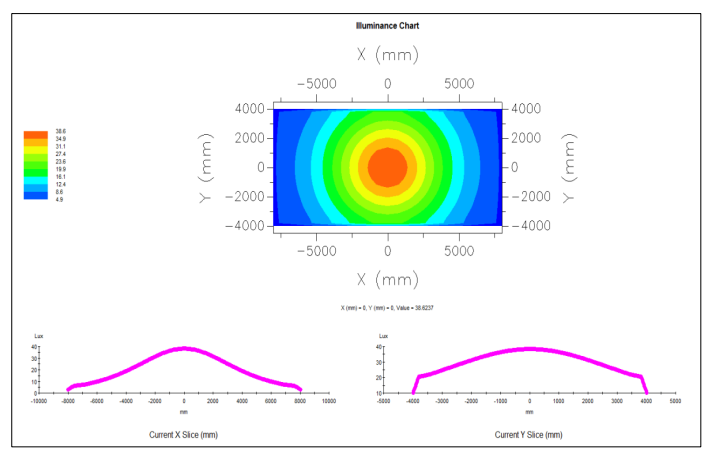

(c) $6 \mathrm{~m}$ 설치 높이의 조도 시뮬레이션

[그림 7] 조도 도표

[Fig. 7] Illuminance Chart 
그림 8은 Illuminance Raster 도표로 LED 모듈에서 나 오는 광이 집중되고 있는 것을 알 수 있다.

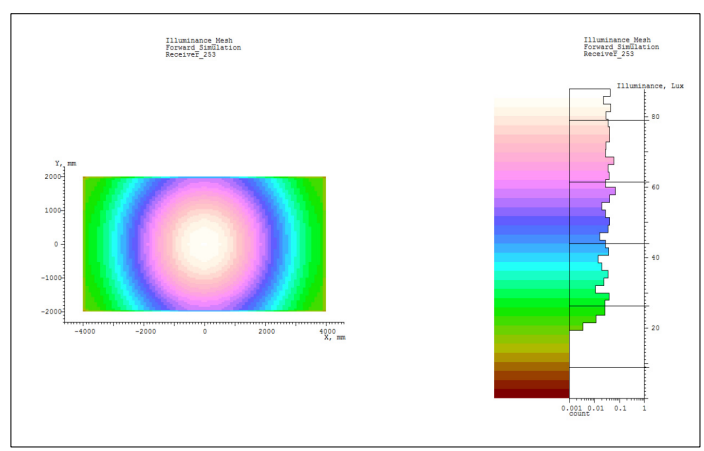

(a) $4 \mathrm{~m}$ 설치 높이의 조도 래스터 도표

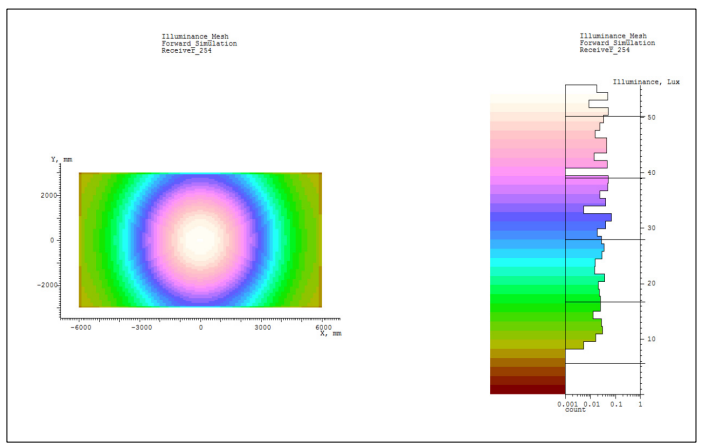

(b) $5 \mathrm{~m}$ 설치 높이의 조도 래스터 도표

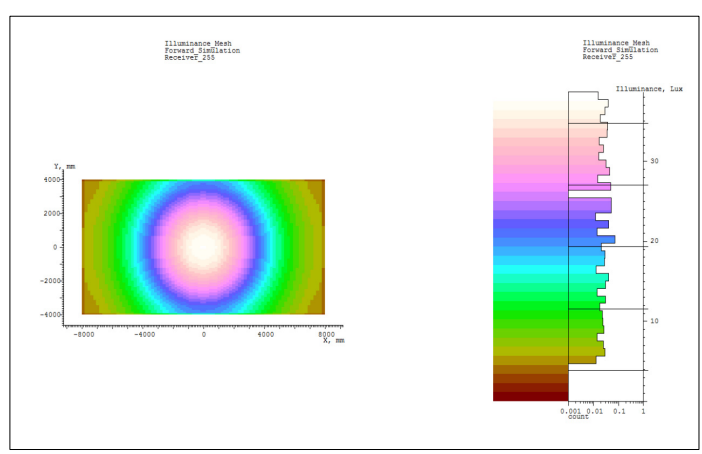

(c) $6 \mathrm{~m}$ 설치 높이의 조도 래스터 도표

[그림 8] 각 수광 높이에서의 조도 래스터 도표

[Fig. 8] Each receiver in the streets illuminance raster chart

그림 9는 LED 발광에 의한 Intensity 도표로 구 좌표계 에서 광의 강도를 표현한 그래프이다. LED 모듈만을 사 용할 때에는 $120^{\circ}$ 램버시안 방사로 직교좌표계에서는 가 우시안 분포에 가깝게 나타남을 그래프를 통해 알 수 있다.

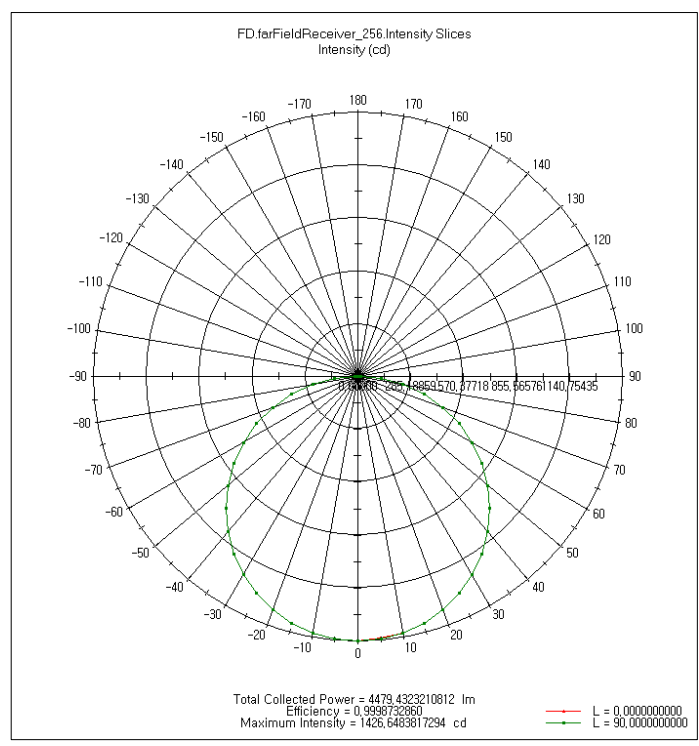

[그림 9] LED 발광에 의한 배광 도표

[Fig. 9] By emitting LED Intensity Chart

그림 10은 LightTools를 이용한 Illuminance 도표로 (a) 는 $4 \mathrm{~m}$ 의 설치 높이에서 $8 \mathrm{~m} \times 4 \mathrm{~m}$ 적용 면적으로 조도를 시뮬레이션 한 데이터이다. 중심부 최대조도는 약 69.5lux, 주변부 최소조도는 약 36.9lux, 평균조도는 약 $54.11 u x$ 를 나타내며, 시뮬레이션에 의한 조도 균제도는 약 0.53 을 나타낸다. 그림 10 의 (b)는 $5 \mathrm{~m}$ 의 설치 높이에 서 $12 \mathrm{~m} \times 6 \mathrm{~m}$ 적용 면적으로 조도를 시뮬레이션 한 데이터 이다. 중심부 최대조도는 약 44.2lux, 주변부 최소조도는 약 17.9lux, 평균조도는 약 31.1lux를 나타내며, 시뮬레이 션에 의한 조도 균제도는 약 0.40 을 나타낸다. 그림 10 의 (c)는 $6 \mathrm{~m}$ 의 설치 높이에서 $16 \mathrm{~m} \times 8 \mathrm{~m}$ 적용 면적으로 조도 를 시뮬레이션 한 데이터이다. 중심부 최대조도는 약 30.9lux, 주변부 최소조도는 약 9.991ux, 평균조도는 약 54.11ux를 나타내며, 시뮬레이션에 의한 조도 균제도는 약 0.32 을 나타낸다. 그림에서 보는 바와 같이 $\mathrm{LED}$ 의 중 심으로 모이는 광을 주변으로 확산시켜 주는 것을 확인 할 수 있다. 옥외의 경우 조도 균제도는 최소조도/최대조 도로 계산할 수 있다.

그림 11은 Illuminance Raster 도표로 렌즈에서 나오는 광이 균일도를 이루고 있는 것을 확인하였다.

그림 12 는 LED 발광에 의한 Intensity 도표로 구 좌표 계에서 광의 강도를 표현한 그래프이다. $\mathrm{x}$ 축을 따라 약 $150^{\circ}$ 의 넓은 배광 분포를 보이고 있다. 이 배광 분포는 배트윙 형태로 기본 LED모듈만의 $120^{\circ}$ 램버시안 방사에 서 가지지 못한 균제도 특성을 가지고 있다. 


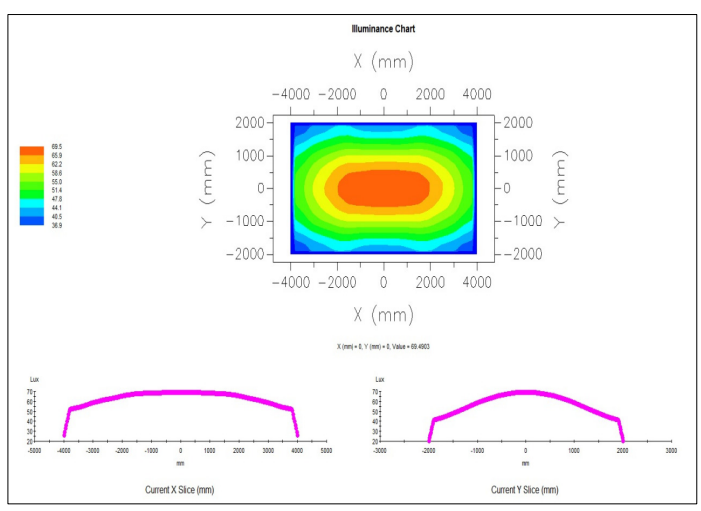

(a) $4 \mathrm{~m}$ 설치 높이의 조도 시뮬레이션(렌즈 적용)

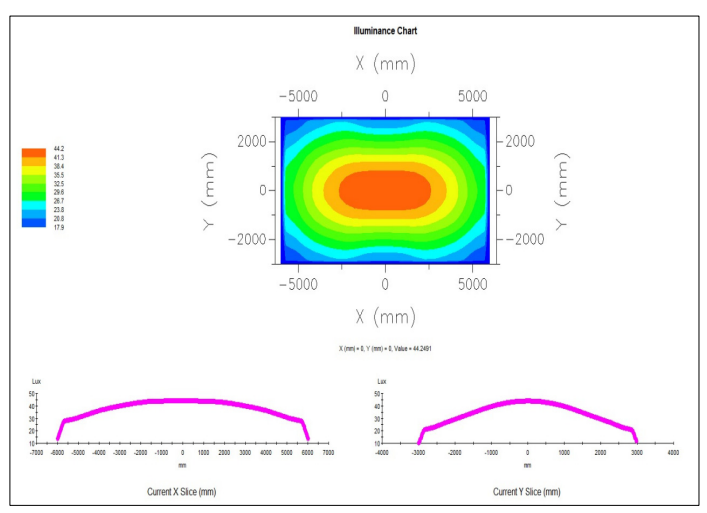

(b) $5 \mathrm{~m}$ 설치 높이의 조도 시뮬레이션(렌즈 적용)

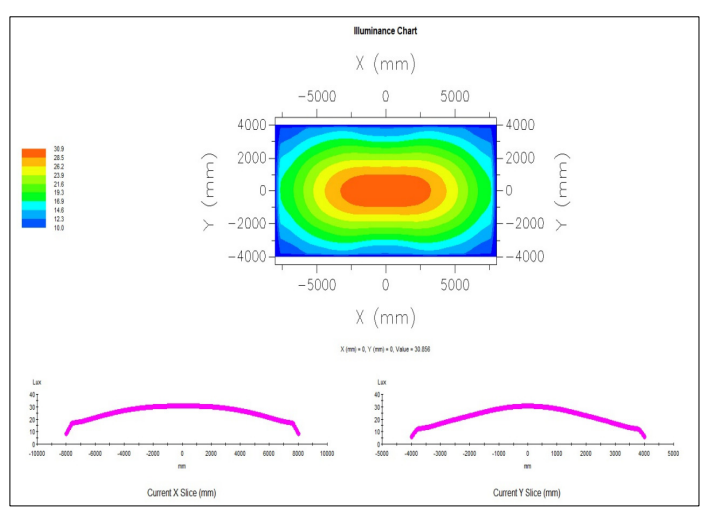

(c) $6 \mathrm{~m}$ 설치 높이의 조도 시뮬레이션(렌즈 적용)

[그림 10] 조도 도표(렌즈 적용)

[Fig. 10] Illuminance Chart(Apply lens)

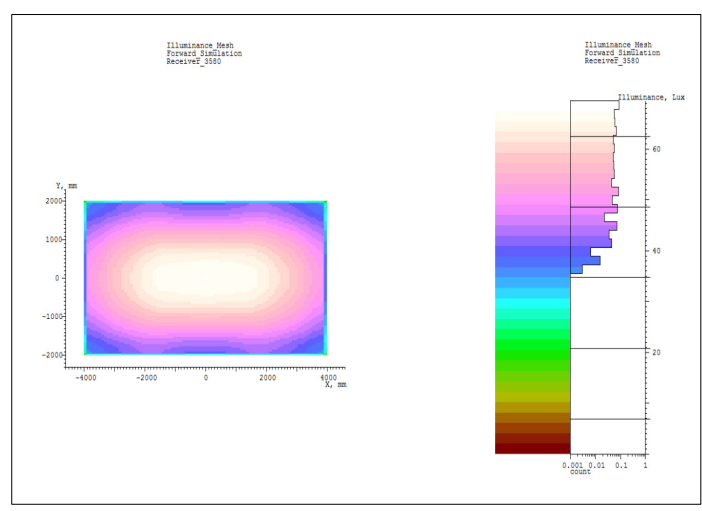

(a) $4 \mathrm{~m}$ 설치 높이의 조도 래스터 도표(렌즈 적용)

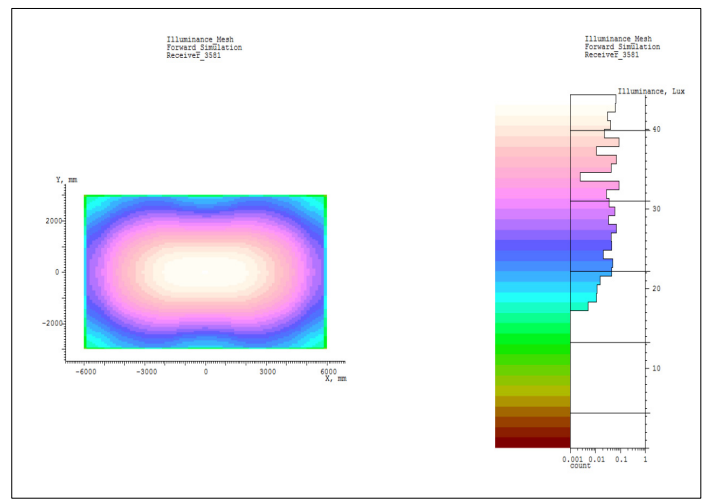

(b) $5 \mathrm{~m}$ 설치 높이의 조도 래스터 도표(렌즈 적용)

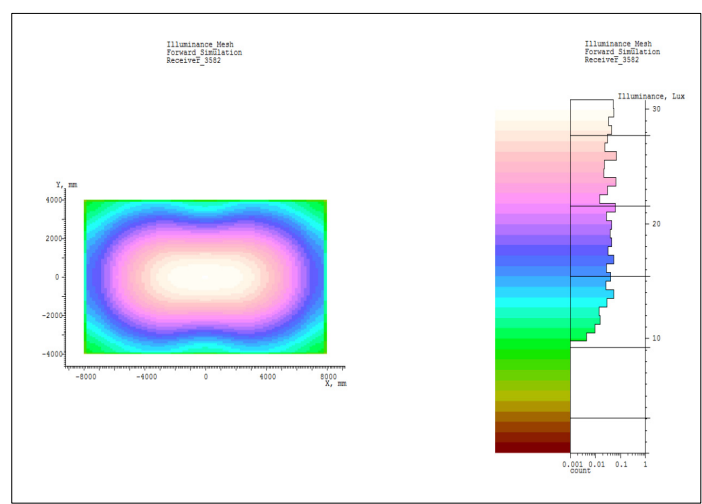

(c) $6 \mathrm{~m}$ 설치 높이의 조도 래스터 도표(렌즈 적용)

[그림 11] 각 수광 높이에서의 조도 래스터 도표 (렌즈 적용)

[Fig. 11] Each receiver in the streets illuminance raster chart(Apply lens) 


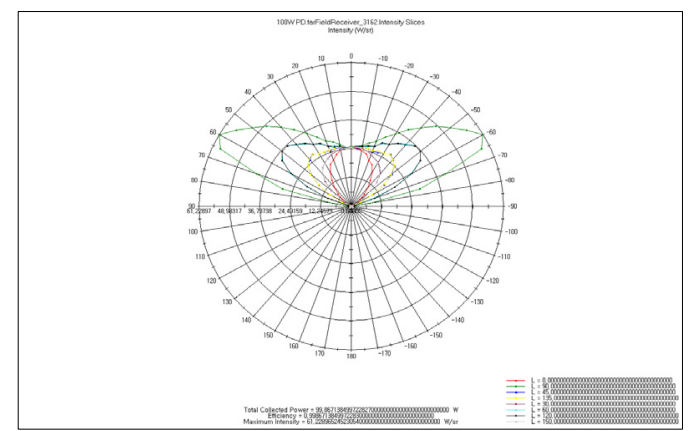

[그림 12] LED 발광에 의한 배광 도표(렌즈 적용) [Fig. 12] By emitting LED Intensity Chart(Apply lens)

그림 13 은 개발된 광학계를 적용한 LED 조명 6개를 설치 높이 $6 \mathrm{~m}$ 로 하여 $\mathrm{x}$ 축으로 $14 \mathrm{~m}$, $\mathrm{y}$ 축으로 $7 \mathrm{~m}$ 의 거리 로 배열하여 시뮬레이션 한 결과이다. 광 패턴의 변화가 적으면서 광이 균일하게 분포되게 하기 위하여 LED 등 기구 간격을 $14 \mathrm{~m} \times 7 \mathrm{~m}$ 로 시뮬레이션 하였다. 서로 조화 를 이루어 조도 균제도를 높게 유지하도록 하였다.

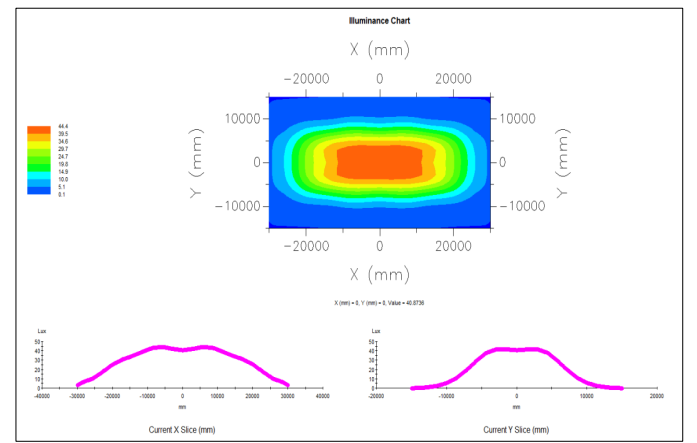

(a) $6 \mathrm{~m}$ 설치 높이, $14 \mathrm{~m} \times 7 \mathrm{~m}$ 등간격의 조도 시뮬레이션

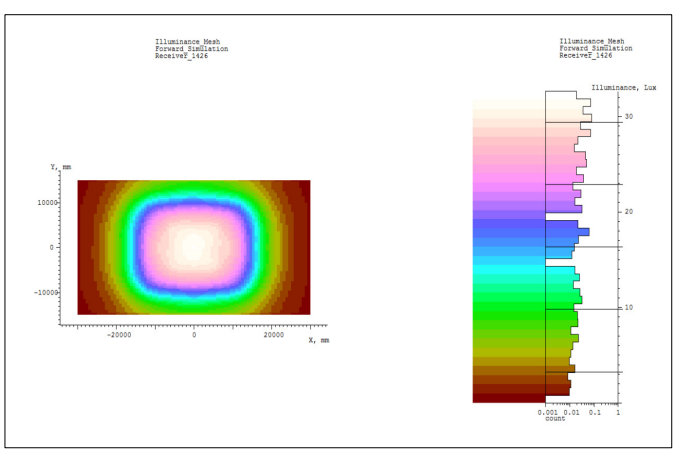

(b) $6 \mathrm{~m}$ 설치 높이, $14 \mathrm{~m} \times 7 \mathrm{~m}$ 등간격의 조도 래스터 도표

[그림 13] 다중 배열 시뮬레이션

[Fig. 13] Simulate a multi-dimensional array

\section{2 광학계 성능 실험 및 평가}

\subsection{1 실험장비}

광학계 설계와 조명 시뮬레이션 결과를 토대로 그림 14 의 개발 광학계 Mock-up을 제작하였다. 개발 광학계 Mock-up의 재질은 PMMA이며, 폴리싱 머신으로 비구면 을 가공하였다.

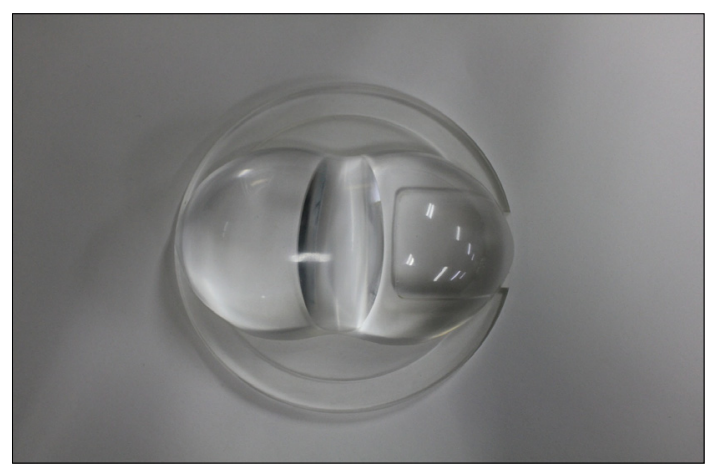

[그림 14] 개발 광학계 Mock-up 제품

[Fig. 14] Mock-up product development of optic

개발 광학계와 매치하여 사용할 LED 모듈은 Bridgelux사 의 Multi Chip Array 모듈로 LED의 용량은 51.6W이다. 그림 15의 BXRA-C5000으로 개발한 광학계 Mock-up과 결합하여 조도 및 균제도 특성을 분석하였다.

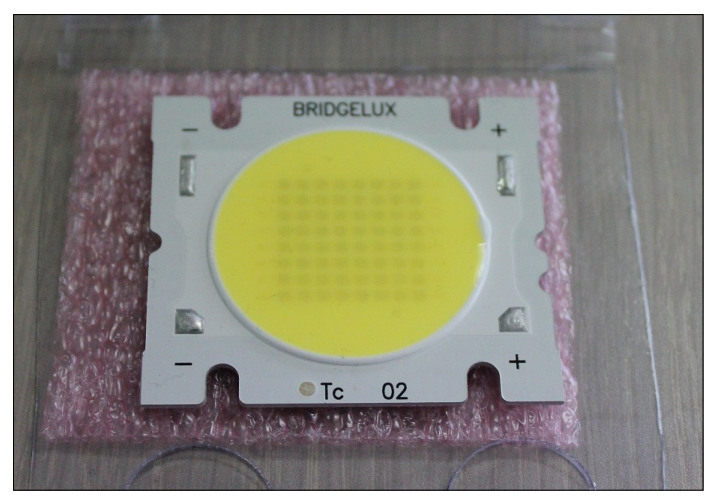

[그림 15] 실험 LED 모듈

[Fig. 15] LED modules for the experiment

그림 16은 개발한 Mock-up 광학계를 LED 모듈과 방 열판 등을 결합하여 $\mathrm{LED}$ 보안등 점등 사진을 나타낸다. 


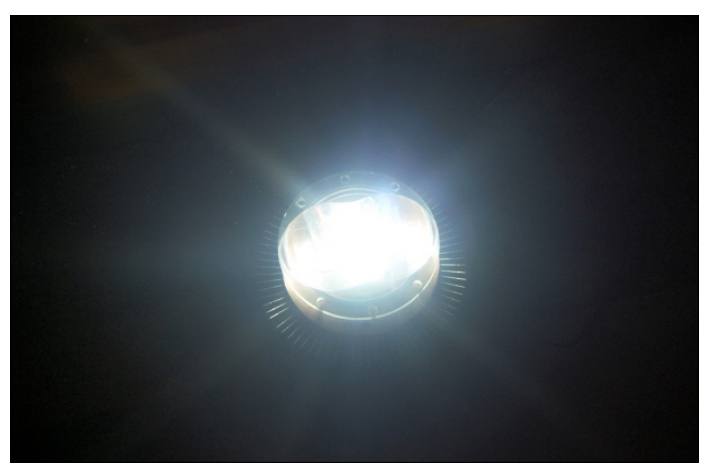

[그림 16] 개발 LED 보안등

[Fig. 16] Security and stores LED development

\subsection{2 실험결과}

개발한 LED 보안등의 광학적 특성을 도로 조명 기준 (KS C 7658:2011)으로 한국광기술원에서 측정하였다. 그 림 17 은 각각 $4 \mathrm{~m}, 5 \mathrm{~m}, 6 \mathrm{~m}$ 설치 높이에서 조도를 측정한 결과이다. 그림 17 의 (a)는 $4 \mathrm{~m}$ 설치 높이의 조도 측정 결 과이며, 최소 30.7lux, 최대 70.6lux, 평균 53.6lux를 나타 내고, 조도 균제도는 0.43 을 나타낸다. 그림 17의 (b)는 $5 \mathrm{~m}$ 설치 높이의 조도 측정 결과이며, 최소 13.0lux, 최대 45.0lux, 평균 30.4lux를 나타내고, 조도 균제도는 0.29을 나타낸다. 그림 17 의 (c)는 $6 \mathrm{~m}$ 설치 높이의 조도 측정 결 과이며, 최소 6.7lux, 최대 31.4lux, 평균 19.3lux를 나타내 고, 조도 균제도는 0.21 을 나타낸다.

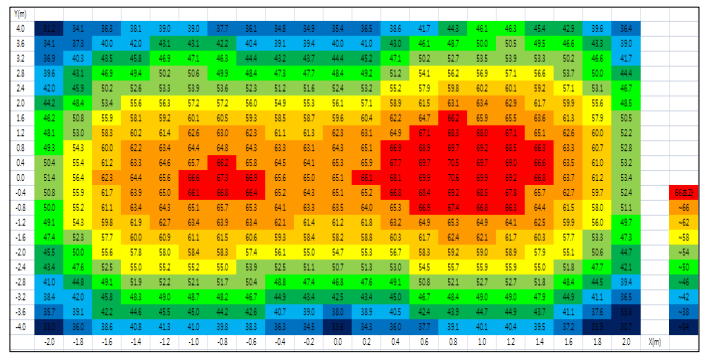

(a) $4 \mathrm{~m}$ 설치 높이의 조도 측정

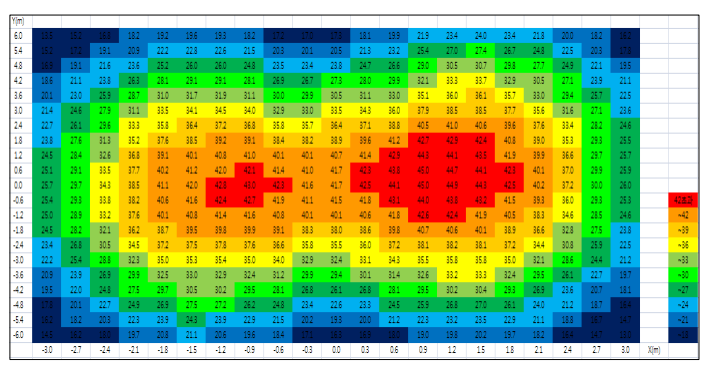

(b) $5 \mathrm{~m}$ 설치 높이의 조도 측정

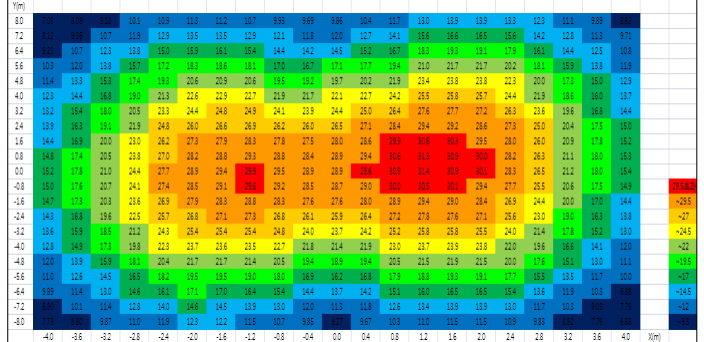

(c) $6 \mathrm{~m}$ 설치 높이의 조도 측정

[그림 17] 개발 광학계 측정 결과

[Fig. 17] Results of measurements optical system

그림 18 은 LED 보안등 Mock-up의 조도 측정 결과를 $\mathrm{x}$ 축과 $\mathrm{y}$ 축 선상으로 비교한 그래프이다. 개발광학계를 사용하였을 때 $\mathrm{x}$ 축 상으로 중심의 광이 주변으로 분산되 는 것을 확인하였다. LED 만을 사용할 때에는 램버시안 방사로 직교좌표계에서는 가우시안 분포에 가까우며 그 화각은 일반적으로 중앙부의 $\mathrm{Max}$ 파워의 $50 \%$ 가 되는 Radiation 파워로 보통 $120^{\circ} \pm 10^{\circ}$ 로 보고 Day Light과 같 은 광균일도는 나오지 않는 문제점이 있다. 이러한 LED 모듈에 배광 조절 렌즈를 사용하면 중앙부에 있는 Max 파워가 좌우로 이산되며, 일정 면적 이상으로 파워를 분 산시켜 LED가 갖는 고유의 눈부심이 억제되며 효과적으 로 넓은 면적을 조사할 수 있음을 알 수 있다.

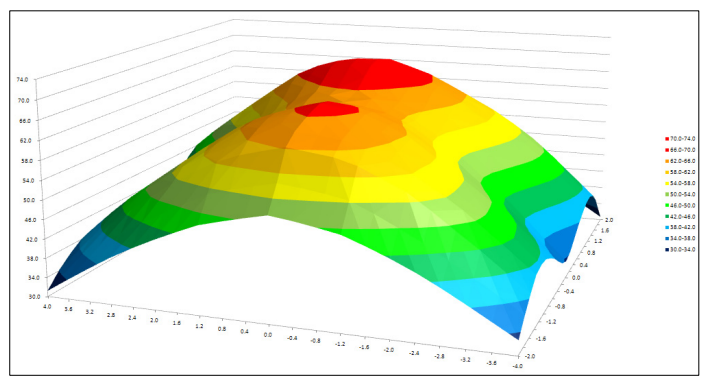

(a) $4 \mathrm{~m}$ 설치 높이의 조도 측정

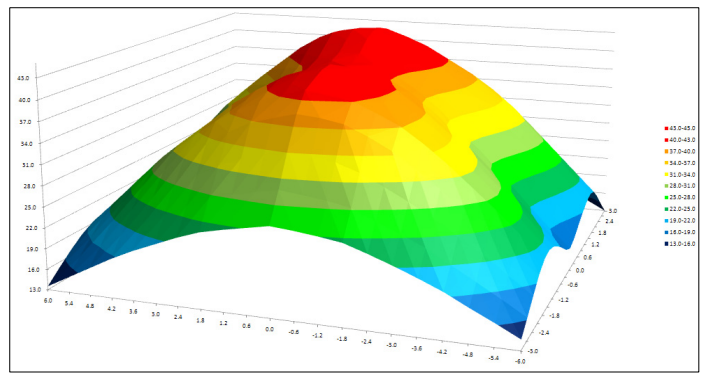

(b) $5 \mathrm{~m}$ 설치 높이의 조도 측정 


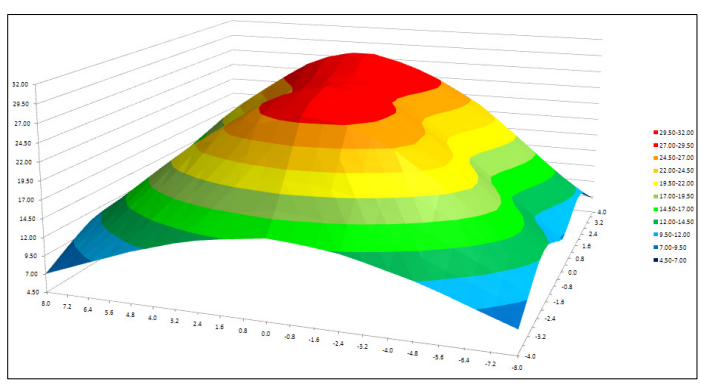

(c) $6 \mathrm{~m}$ 설치 높이의 조도 측정

[그림 18] 개발 광학계 측정 결과 그래프

[Fig. 18] A graph of the results of measurements optical system

\section{4. 결론}

본 연구에서는 광 조정 2차 렌즈를 적용한 $\mathrm{LED}$ 조명 등을 개발하여 다음과 같은 결론을 얻을 수 있었다.

(1) LED 가로등 및 보안등 기구 도로 조명 기준(KS C 7658:2011)의 보안등 기구의 높이 기준인 $4 \mathrm{~m}, 5 \mathrm{~m}$, $6 \mathrm{~m}$ 설치 높이에서 실험 한 결과 $\mathrm{LED}$ 의 중심으로 모이는 광을 주변으로 확산시켰으며, 평균노면 조 도는 각각 53.6lux, 30.4lux, 19.3lux로, 이는 교통량 과 관계없이 야간보행자가 보행 가능한 평균조도 이상으로 나왔음을 알 수 있다.

(2) 또한, 조도 균제도도 각각 $0.43,0.29,0.21$ 로 나와 균제도 기준치인 0.15 이상으로 나오는 것을 알 수 있었다.

(3) Mock-up 제작 후 배광측정기를 이용하여 배광을 측정한 결과 개발 $\mathrm{LED}$ 조명등이 $150^{\circ}$ 의 넓은 배 광분포를 가지는 것을 확인하였다.

(4) 본 연구를 통해 개발된 2차 광학계를 이용하여 $6 \mathrm{~m}$ 용 LED 보안등 기구를 개발하면 조명기준 중 광 학적 특성과 관련된 평균노면 조도와 조도 균제도 부분은 충분히 해결될 것으로 사료된다.

\section{References}

[1] Kai Wang., "Novel Application-Specific LED Packaging with Compact Freeform Lens", 2009 Electronic Components and Technology Conference. pp. 2125 2130, 2009.
[2] S. Y. Choi, I. S. Yeo, S. M. Lim, "LED Lens Design for the Improvement of Illuminance Uniformity", Conference on the Korean Institute of Electrical Engineers, pp.1607 1608. 2009.

[3] B. M. Jung, S. B. Han, H. G. Jeong, "New Lighting Technologies", ECOT, pp.1 7, 2001.

[4] B. S. Kim, O. Y. Yim, "Analysis of Light Environment and Building Energy Performance of LED Lamp Installed in Office Building," Journal of the Architectural Institute of Korea, Vol. 25, No. 7, pp. 329 336, July 2009.

\section{정 병 조(Jeong Byoung-Jo)}

[정회원]

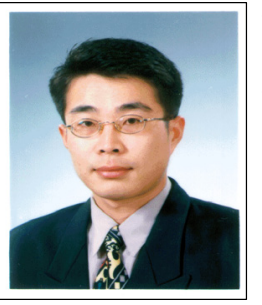

- 2002년 2월 : 원광대학교 전기전 자공학부(공학사)

- 2004년 2월 : 원광대학교 대학원 전기공학과(공학석사)

- 2004년 3월 현재 : 원광대학 교 대학원 전기공학과(박사과정)

- 2010년 6월 현재 : (주)창전사 책임연구원

<관심분야>

자동제어, 영상처리, $\mathrm{LED}$ 조명

\section{장 성 환(Jang Sung-Whan)}

[정회원]

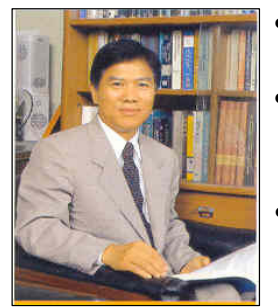

- 1982년 2월 : 연세대학교 대학원 전기공학과(공학박사)

- 1985년 3월 1986년 2월 : Northwestern University 전기및 컴퓨터학과 방문교수

- 2005년 1월 2006년 1월 : Mississippi State University 컴 퓨터사이언스공학과 교환교수

- 1980년 3월 현재 : 원광대학교 전기정보통신공학부 교수

<관심분야>

자동제어, 지능제어 및 응용, $\mathrm{LED}$ 조명 
노 용 기(Yong-Gi, Roh)

[정회원]

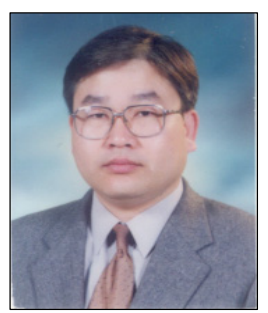

- 1991년 2월 : 원광대학교 전기공 학과(공학사)

- 1995년 2월 : 건국대학교 전기공 학과(공학석사)

- 2006년 8월 : 원광대학교 전기공 학과(공학박사)

- 1996년 12월 현재 : KCCI 전

북인력개발원 전기시스템제어공

과 전임교수

<관심분야>

자동제어, Neural-Fuzzy, 계장제어, RFID, LED 조명 